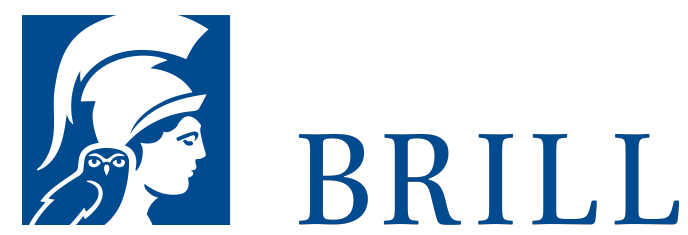

\title{
Papsttod und Weltöffentlichkeit seit 1878
}

Die Medialisierung eines Rituals

Author: René Schlott

Als Johannes Paul II. am 2. April 2005 starb, schaute die Welt nach Rom. Tageszeitungen erschienen in Extraausgaben, Radiound Fernsehsender unterbrachen ihr laufendes Programm. Das Medienereignis »Papsttod « trat beim Tod Johannes Pauls II. nicht zum ersten Mal in Erscheinung. Die überragende Stellung, die der Papst als Oberhaupt der katholischen Kirche innehat, sorgte dafür, dass sein Ableben auch in der Vergangenheit immer als eine bedeutende Zäsur wahrgenommen wurde und eine entsprechende grenzüberschreitende Medienpräsenz erfuhr. Mit der Entstehung der Massenmedien im letzten Drittel des 19. Jahrhunderts steigerte sich die Medienaufmerksamkeit für den Tod des Papstes bis hin zu ihrem Höhepunkt im April 2005 .

Kontinuitäten und Veränderungen im Ritual: Der Tod der Päpste als Medienereignis in historischer Perspektive.

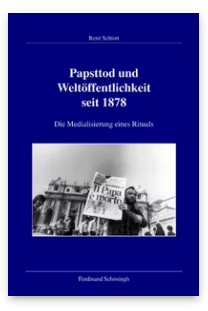

Pages: 270

Seiten, 4 s/w und 6 farb. Abb.

Language:

German

Subjects:

General, Theology and

World

Christianity

Publisher: Brill |

Schöningh

Series:

Veröffentlichungen der Kommission

für Zeitgeschichte, Reihe B:

Forschungen,

Volume: 123

E-Book (PDF)

Released online: 28 Apr 2020

ISBN: $978-3^{-}$

657-77361-9

List price

Hardback

Publication date: 11 Mar 2013

ISBN: 978-3506-77361-6 List price 
Biographical Note

René Schlott ist seit 2012 Lehrbeauftragter am Historischen Institut der Universität Gießen.

For more information see brill.com

\begin{abstract}
Order information: Order online at brill.com
+44330 333 o049 | customerservices@brill.com

Submission information: brill.com/authors
\end{abstract}

Titles published by Brill | Fink, Brill | mentis or Brill| Schöningh: +49(o)71 5413279216 | brill@brocom.de 